\title{
Research on the Cultivation Mode of Financial Service Outsourcing Talents
}

\author{
QiaolingFu, Rui Zhao \\ School of Management,Beijing Union University, Beijing, China
}

\begin{abstract}
With rapid development of financial serviceoutsourcing industry, more and more attention is placed on talent training mode. The purpose of this article is to make comparative study on the main talents cultivation mode developed by colleges and universities, and put forward that talent cultivating programs for financial service-outsourcing talents. Based on extensive investigation, categorized the KAQ demands for different level of talents, the results are as follows: The combination with local economy and service outsourcing industrial development trend to formulate financial service outsourcing talents cultivation scheme and the adoption of large category enrollment mode to cultivate "practical, innovative and international" high-end financial service outsourcing talents are proposed in this paper, meanwhile to enhance the innovation ability of this type of talents is also important.
\end{abstract}

Index Terms - colleges and universities, financial service outsourcing, talents cultivation

\section{Introduction}

Financial service-outsourcing (FSO) is the key industry in service outsourcing, including three major fields such as Business Process Outsourcing (BPO), Information Technology Outsourcing (ITO) and Knowledge Process Outsourcing (KPO). With the accelerated separation between foreground and background of international financial industry and constant segmentation of labor division in the background, the development of FSO has been developing rapidly in recent years. It has developed to the trend from "making up the shortage of resources by taking advantage of external technologies and resources" in early stage to "outsourcing the departments other than core businesses as much as possible" at present ${ }^{1}$. And BPO and KPO are under accelerated development based on the constant development of traditional ITO.

The global FSO's outsourcing client markets are concentrated in such countries and areas as North America, Europe, Japan and Korea at present. Viewing from industrial distribution, banking service outsourcing, which is taking the leading role, accounts for as high as $61 \%$, while securities and insurance accountfor $23 \%$ and $16 \%$ respectively. The annual average growth rate of ITO of the world's 15 largest financial enterprises reached 34\% between 2005 and 2010 . The services worth of 356 billion dollars (accounting for around $15 \%$ of the total costs of America's financial industry) in America's financial service industry in 2010 alone had been outsourced to overseas. The contracting markets of global FSO are mainly distributed in the emerging and developing countries such as India, China, Ireland, Philippine

\footnotetext{
${ }^{1}$ Wang Li, Liu Chunsheng, Huang Yuhua. China Service Outsourcing Development Report (2010-2011), Social Sciences Academic Press, August, 2011
}

and Brazil in Asia and East Asia areas. China, India and Philippine undertake around $60 \%$ of the total shares in global service outsourcing industry. China is expected to become the second largest FSO nation next to India. China not only has comparatively strong capacity in contracting offshore outsourcing business, but also local financial institutes are having more and more demands on onshore outsourcing. Comparing with India, such a leading country in FSO, China's competitive power mainly embodies in stable society, sustained economic growth, good infrastructures and competitive comprehensive costs. However, it is hard to satisfy the development of FSO industry in human resource reserve. Therefore, the issue of improving the cultivation of FSO talents has received more and more concerns. And different type of colleges and universities are also exploring FSO's talents cultivation modes in different ways.

\section{FSO Talents Demand Analysis}

\subsection{Talent types demanded by contract-issuing party and contractor party are different}

No matter the financial institutions, the contract-issuing party, or the service outsourcing enterprises, the contractor, are both the major demanders for FSO talents. However their talents demanding types are different. There are mainly two types of contract-issuing enterprises: first type, China's local financial institutions (including banks, insurance companies and securities companies), and the second type is the foreign-funded financial institutions such as HSBC, Citibank and Standard Chartered Bank. And the talents needed by them are mainly outsourcing management talents. There are three types of contractor enterprises: first type, the subsidiaries or internal institutions which are established by foreign-funded financial institutions in China to undertake offshore outsourcing businesses; second type is the branch institutions of international large scale outsourcing enterprises established in China, such as Accenture, Capgemini, FDC and IBM, as well as Indian enterprises including Tata and Satyam; and the third type is local FSO providers such as China Data Group, Global Data Solutions Limited and China Unionpay Data Services Co., Ltd.

\subsection{The KAQ demands for different level of talents are different}

FSO talent is a kind of inter-disciplinary talent with "IT skill + financial knowledge". In offshore financial outsourcing, talents must be equipped with knowledge in IT, finance and foreign language. As China's offshore outsourcing mainly involves with the outsourcing businesses from Japan, Korea 
and Europe and America, so a qualified outsourcing talent should master the reading, writing and oral communication skill in English, Japanese and Korean. And the high-end talents (such as project manager, process manager, quality manager and communication manager) are usually required to have excellent abilities in project management, team management and personnel management and interpersonal relationship disposal skill, while the top management talents must know well the international service outsourcing enterprises' working and management modes, and be equipped with the abilities in grasping the direction, comprehensive survey of general situation, formulating fundamental policies and strategic decision-making. In addition, due to the particularity of financial industry, FSO personnel will usually get to know clients' business secrets, so whatever level the talent is, he must have very good professional ethics to safeguard clients' secrets. Of course, the higher level the talent is, the more important his innovation ability is.

\subsection{High-end talent with innovation ability is the focal point of talent demand and industrial competition}

In the next few years, the speed for labor intensive BPO service to expand to second and third-tier cities will be faster than that of ITO. And the outsourcing industry which is focused on "smart service" and "professional service", such as high-end consultation, financial products development and financial software development, will become the mainstream of the financial centers like Beijing. Beijing will take the lead to enter the next stage of industrial upgrading - the traditional FSO industry which aims at "decreasing costs for clients" will gradually fade out, and be replaced by a new type of outsourcing industrial mode with "sharing smart service" as its core, and innovation service and creation service will become the competition focus. The talents with innovation awareness and innovation ability will create more value for enterprises.

\section{Analysis on the Supply of High-end FSO Talents}

\subsection{Serious imbalance between supply and demand}

3.1.1. Imbalance between the numbers of supply and demand

According to the statistics issued by the Ministry of Commerce, there were 4.695 million people in service outsourcing industry in China by the end of 2012, among which there were 3.171 million people holding a college degree or above, accounting for $67.54 \%$. In the first 6 months of 2013, China's service outsourcing industry newly increased 406000 employed people, among whom there were 258000 college graduates with a year-on-year growth of $8.4 \%$, accounting for $3.7 \%$ of the total college and university graduates of the year. And the rapid growth of China's financial industry provides great development space for China's FSO industry. The total assets of China's banking financial institutions were 113.3 trillion RMB in 2012, increased by $478 \%$ in ten years. However, there were only 1.5 billion RMB in FSO market, only accounting for $0.2 \%$ of global FSO market share (1.2 trillion dollars). At present, there are 21 service outsourcing demonstration base cities in China, and 22 cities which propose to establish financial background center at the mean time. Therefore, China's demand for FSO talents will flourish in the next few years. However, the effective supply of FSO talents is in serious shortage in view of the giant demands on talents by the enterprises in this industry. As the FSO specialty established by China's colleges and universities is under starting stage, so the number of cultivated talents is very limited.

\subsubsection{Conflicts in the structure of supply and demand}

Firstly, China's FSO industry has great demands on high-end talents, but colleges and universities cannot directly cultivate this type of talents, so they are mainly sourced from the senior employees from domestic and abroad related industries. Secondly, China's FSO industry also lack of the middle level talents. This level of talents are required to have Bachelor's Degree or above, and they are the major objects cultivated by China's colleges and universities. However, many enterprises feel that it is very difficult to find suitable employees from new college graduates. The market is in particular shortage of the inter-disciplinary talents who know computer skills, English, finance and management. The training costs for new college graduates are very high, so a lot of enterprises have to find talents from the industry. Thirdly, the development of China's FSO industry, especially BPO, is still under the initial stage. As a result, a lot of local BPO companies' businesses focused on low-end services which feature in simple operation and high repetition, such as data entry, physical parts service and calling center service. However some companies have serious high consumption problems among operation-type low-end post talents.

\subsection{Talents cultivation in colleges and universities is focused on non-order-oriented cultivation}

Viewing from talents cultivation specialties, domestic colleges and universities mainly take computer and information science specialty and economic management specialty as the basics for cultivating FSO talents. The talents cultivation based on computer and information science specialty is aimed to cultivate financial ITO talents, to highlight IT technology and to focus on bank information center and ITO enterprises for employment. And the economic management specialty mainly cultivates BPO talents. It highlights the process management and foreign language communication of financial institutions. And the employment targets on financial background service industry.

Viewing from the levels of talents cultivation, colleges and universities cultivate talents from three levels including master's degree holders, bachelor's degree holders and higher vocational degree holders to meet with the demands on different jobs. In the level of master's degree holders, it not only cultivatesinter-disciplinary talents by utilizing cross-disciplines based on IT technology, but also, highlights students' management and innovation abilities; the cultivation for bachelor's degree holders highlights more on cross-disciplines and foreign language communication ability; while the education on higher vocational degree holders 
mainly targets on cultivating FSO's top-class talents. Generally speaking, there are only a few colleges and universities focused on high-end FSO talents cultivation.

In talents cultivation mode view, it can be divided into order-oriented cultivation and non-order-oriented cultivation. The advantages of order-oriented cultivation are that it is more targeted, and students' employment direction is clearer, but students' employment choices are narrow and their career scalability is weak. Non-order-oriented cultivation can be divided into two modest: setting FSO specialty (such as University of International Business and Economics and International Service Engineering School of Hangzhou Normal University) and embedding service outsourcing curriculum modules (like Beijing Union University). Among them, the first type of talent cultivation mode is more targeted and more intensive, while the second type has strong target but narrow employment choices for students.

Viewing from the areas where the colleges and universities are located, the colleges and universities in first-tier cities tend to cultivate high-end and medium and high level talents, while that in second-tier cities tend to cultivate middle level and first-line skill-oriented talents.

Viewing from the cultivation goals, cultivating practical and technical talents are the common goals of most colleges and universities. And only a few universities mention about cultivating talents' innovation ability.

\section{Construction of Cultivation Mode for High-end FSO Innovative Talents}

\subsection{Confirm the high-end talents cultivation goal that suitable for the development of FSO industry}

According to the talents demand features in FSO industry, the goal of cultivating practical, inter-disciplinary and international talents formulated by colleges and universities has gradually become a consensus. However, in terms of the talents cultivation goal, it should be clarified that practical talents does not mean operational talents, and it requires quality-oriented education to guarantee the scalability of talents' future career; inter-disciplinary talents does not mean multiple subjects, but means the provision of inter-disciplinary knowledge for the talents so as to enable them to analyze and handle with the services and problems which involve with multi-subjects, multi-institutions and multi-cultures, and to be equipped with specific professional skill and potential for management work; and international talents doesn't mean strengthen foreign language ability, but means to make the talents to have cross-cultural comprehensive ability and communication ability based on knowing international rules.

\subsection{Integrate innovation ability cultivation into the whole process of high-end FSO talents cultivation}

FSO talents cultivation highlights in talents' practice ability. However, practical talents are not the "executive" talents who only know how to operate or practice. And their innovation capacity cannot be neglect. As the final development of FSO industry depends on that if outsourcing enterprises can provide innovative service for their clients, while such innovative service depends on talents' innovation ability. The innovation ability will be the main issue for talents cultivation in colleges and universities and the talents demand by FSO enterprises in the future. The cultivation of FSO innovative talents includes one important thing, which is to integrate innovation ability into the entire process of talents cultivation. Of course, the objects to whom cultivate innovation ability are not concentrated in a few "top-notch personnel" but for all students. The requirements for the innovation cultivation for different levels and different types of talents are different. Management-oriented talents stress on strategic innovation and management innovation; technology-oriented talents highlight in technical innovation and service innovation; while operation-oriented talents emphasize on process innovation and service innovation students' innovation awareness and innovative thinking should be mainly cultivated during cultivation process so as to form innovation ability. And innovation ability cultivation should be integrated into the entire process of education during talents cultivation planning.

Colleges and universities should plan talents cultivation process with innovation ability cultivation as the main line when building FSO talents cultivation scheme. Furthermore, they should systematically optimize such key links as curriculum system, course teaching, teaching staff, students' practice and teaching management. This will mainly embodies in the cooperation among colleges and universities, training institutions and enterprises. During talents cultivation process, they should take cultivating students' innovation concept as the entry point and thus to cultivate students' innovation spirit, to promote students' to form innovative thinking and then finally to form creative ability.

\section{Conclusion}

The countermeasures for the cultivation of high-end FSO innovative talents in China are proposed through above analysis in this paper:

\subsection{Cultivate high-end FSO talents with the method of embedding curriculum module}

To those practical universities with comparatively complete subjects and specialties, their subject settings and school-running orientation can play an all-around support role for FSO talents cultivation. Particularly in financial BPO talents cultivation, they can better realize cross-discipline and thus establish "cross-discipline" curriculum system. Meanwhile, by flexibly embed selected service outsourcing curriculum module into talents cultivation scheme based on satisfying students' personalized choice, it can not only meet with the demands in this industry, but also lay a solid foundation for students' inter-disciplinary knowledge reserve and diversified development. Such kind of FSO talents cultivation mode is work of discussion. Figure 1 is the curriculum system for FSO talents cultivation established by Finance Specialty, School of Management, Beijing Union University. This system conducts FSO talents cultivation through increasing elective FSO modules (including Service 
Outsourcing Introduction, Financial Business Process Management and Practice, Data Processing and Analysis) under the premise of satisfying the talents demand by traditional financial institutions. It not only expands students' employment fields, but also increases students' employment flexibility.

\subsection{Improve talents' creative and practical abilities in "three-party cooperation" method}

FSO talents are practical talents and their practicality mainly embodies in practice. How does school build off campus practice base; establish imitated practical teaching environment; attract enterprises to attend training courses design and teaching; and even introduce enterprises' projects into teaching; carry out diversified posts training and entrepreneurship education to all students through vivid practical teaching; and provide enterprises' internship and training opportunities for students are the keys for practically implement FSO talents cultivation. Viewing from wider fields, colleges and universities are one of the channels and links for FSO talents cultivation. Colleges and universities must cooperate with social training institutes and service outsourcing enterprises to conduct talents cultivation with colleges and universities being responsible for professional knowledge and quality training for talents, social training institutes in charge of developing special curriculum, while service outsourcing enterprises being liable for providing training and practice bases. However, domestic FSO training institutes are still under starting stage at present. The subsidy policy provided for service outsourcing enterprises and service outsourcing training institutes by China's government has been greatly boosting domestic training institutes since 2009. Abroad training institutes such as NIIT and GTT from India have also been speeding up their steps in China. Colleges and universities must find a way to realize seamless joint between graduation and employment of students from colleges and universities, to improve training efficiency of training institutes and to provide stable talents source and decrease training costs for enterprises through the cooperation among colleges and universities, training institutes and enterprises under their own talents cultivation framework, and thus to realize "triple-win cooperation".

\subsection{Improve high-end FSO talents' foreign language application ability}

Colleges and universities must pay attention to cultivate students' comprehensive application ability in foreign language, especially listening and speaking ability, so as to enable them to use foreign language to make effective oral and written communication and result delivery when working in service outsourcing industry. Taking English as example, related specialties must increase the credit hours for English learning, especially that for oral and writing studies. It should not only set up the course for basic English, but commercial English too, and oral English learning in particular. In addition, bilingual courses can be set up in professional courses or targeted service outsourcing English study can be set up.

At present, such key service outsourcing nations as India and Philippine have all been concerning about the upgrading of service outsourcing industry, mainly focused on developing high-end service outsourcing with high added value and technical content. The competition on service outsourcing market will eventually evolve to be the talents competition among all nations. All colleges and universities must enhance their cooperation with enterprises and training institutes and choose reasonable talents cultivation modes according to their own resources and advantages by combining with local talents demand.

\section{References}

[1] LiuRui-Lin, "Research on experimental teaching system of financial service-outsourcing talent cultivation", Computer Education, vol. 99, no. 15, pp. 95-97, Sep 2001

[2] Wu-shu, "Research on enterprise competitiveness of BPO in financial service industry in China," MA.E. dissertation, Dept. Elect. China, Beijing Univ., Beijing, 2007.

[3] Yang-lin, Wang-Jiajia, "financial service-outsourcing: international trand and the choice of China, Beijing: People's Publishing House, 123-124, May 2008.

[4] li-Tinghui, "Research on industrial policy of financial service-outsourcing in ShangHai," New Finance, vol. 232, no. 6, pp. 54-58, Jun 2008.

[5] Wang Li, Liu chunsheng, and Huang Yuhua, "Annual report on Chinese service outsourcing development," Beijing: Social Sciences Academic Press, 35-39, Aug 2011.

[6] Han li, Yang Yi, "Research on cultivation of financial service-outsourcing talent in China," Finance Teaching and Research, vol. 139, no. 5, pp. 71-73, May 2011.

[7] Yang Yi, FuQiaoling, Han li, "Comparative Research on cultivation mode of financial service-outsourcing talent", Beijing Education (Higher Education), vol. 603, no. 5, pp.58-61, May 2012.

[8] BaoHong, ZhouHuali, Shen Hong, "The Training mode reform and innovation for the service-outsourcing undergraduate talents_-A case study of Beijing Union University", China Higher Education Research, vol. 239, no. 7, pp.81-85, July 2013. 